\title{
Prevalence of Catalase (-21 A/T) Gene Variant in South Indian (Tamil) Population
}

\author{
A. Lourdhu Mary, K. Nithya, W. Isabel, and T. Angeline \\ PG \& Research Department of Zoology and Biotechnology, Lady Doak College, Madurai, Tamil Nadu 625002 , India \\ Correspondence should be addressed to A. Lourdhu Mary; lourdhubritto@gmail.com
}

Received 28 February 2014; Revised 5 June 2014; Accepted 5 June 2014; Published 26 June 2014

Academic Editor: Swaran J. S. Flora

Copyright (C) 2014 A. Lourdhu Mary et al. This is an open access article distributed under the Creative Commons Attribution License, which permits unrestricted use, distribution, and reproduction in any medium, provided the original work is properly cited.

\begin{abstract}
Catalase, an endogenous antioxidant enzyme, is responsible for regulating reactive species levels. Several epidemiologic studies have suggested that single nucleotide polymorphism in catalase gene may be associated with many diseases. The genotype of CAT (-21 $\mathrm{A} / \mathrm{T}$ ) point mutation in promoter region of catalase gene was determined by polymerase chain based restriction fragment length polymorphism analysis in the DNA of 100 healthy volunteers. The frequency of CAT (-21 A/T) gene polymorphism AA, AT, and TT genotypes was found to be 7, 23, and 70 percent, respectively. The mutant " $T$ " allele frequency was found to be 0.82 among the south Indian (Tamil) population. Chi square analysis showed that the study population lies within the Hardy-Weinberg equilibrium. The wild type genotype (AA) was found to be very low (7\%) and the mutant genotype (AT/TT) was found to be more prevalent (93\%) among the south Indian population. This suggests that the high prevalence of mutant genotype may increase the susceptibility to oxidative stress associated diseases.
\end{abstract}

\section{Introduction}

Excessive oxidative stress has been implicated in the pathogenesis of several diseases. In humans, the antioxidant enzymes pathway is available to protect against the toxicity caused by oxidative stress. Many of the antioxidant genes are known to be polymorphic, which may alter the enzyme activity [1].

Catalase is an antioxidant enzyme that plays a major role in controlling hydrogen peroxide concentration in human cells. It decomposes $\mathrm{H}_{2} \mathrm{O}_{2}$ into $\mathrm{H}_{2} \mathrm{O}$ and $\mathrm{O}_{2}$, thereby protecting the cells from oxidative stress. It has been suggested that functional polymorphism in the gene encoding catalase enzyme affects the enzyme activity, thereby reducing the protection against oxidative stress [2]. Apart from the decomposition of $\mathrm{H}_{2} \mathrm{O}_{2}$, catalase inactivates many environmental mutagens. It also prevents chromosomal aberration caused by hypoxanthine/xanthine oxidase in Chinese hamster cells [3]. Several studies have reported on the alterations in catalase activity in hypertension [4], cancer [5], diabetes, nephropathy $[6,7]$, and other diseases accompanied by oxidative stress.

Catalase is a homotetramer of $220-230 \mathrm{kDa}$ mass having four heme groups in its structure $[8,9]$. The CAT gene is localized on chromosome 11p 13.31 consisting of 13 exons and 12 introns. CAT $(-21 \mathrm{~A} / \mathrm{T})$ variant represents the $\mathrm{A}$ to $\mathrm{T}$ substitution in the promoter region, which is located inside the promoter region just proximal to the start site [8]. The mutant allele frequency may vary based on the differences in the study population's race and ethnicity and also on the underlying characters.

This study, which has been focused on the genetic variant $-21 \mathrm{~A} / \mathrm{T}$ of the catalase enzyme, was the first kind regarding the prevalence of catalase gene variant in healthy individuals among south Indian Tamil population. The objective was to find out the prevalence of mutant allele frequency of the evaluated catalase $(-21 \mathrm{~A} / \mathrm{T})$ gene polymorphism in healthy individuals among the south Indian population.

\section{Materials and Methods}

2.1. Study Design. A total of 100 healthy controls with no history of cardiovascular disease, diabetes, hypertension, cancer, or any infectious diseases and belonged to south Indian Tamil ethnicity were included for the study. The samples from the volunteers were collected into EDTA coated 


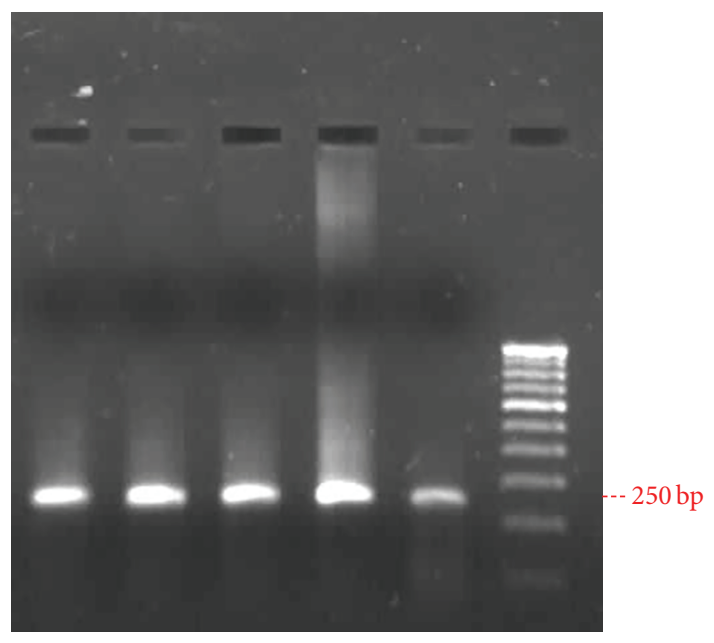

Lane 1-5: PCR product (250 bp)

Lane 6: molecular weight marker (100 bp)

FIGURE 1: PCR analysis of the catalase gene.

tubes and the informed consent was obtained. The present study was approved by the ethical committee and biosafety committee of the institution.

2.2. DNA Extraction. Genomic DNA was extracted from the frozen blood by phenol-chloroform method [10]. For DNA extraction, $500 \mu \mathrm{L}$ of blood was used and the isolated DNA dissolved in TE was stored at $-20^{\circ} \mathrm{C}$. The quality of the DNA was checked in 0.7 percent agarose (Hi-Media, Mumbai) gel electrophoresis and quantified using UV spectrophotometry (Hitachi, Japan).

2.3. PCR Analysis. PCR analysis was carried out using a thermal cycler (Eppendorf Master Cycler, Germany). Approximately $120 \mathrm{ng}$ of genomic DNA was incubated in a total reaction mixture of $50 \mu \mathrm{L}$ containing both the forward primer $5^{\prime}$ AATCAGAAGGCAGTCCTCCC- $3^{\prime}$ and the reverse primer $5^{\prime}$-TCGGGGAGCACAGAGTGTAC- $3^{\prime}$ ( $\sim 70$ picomoles) (GenScript Corp., USA), $200 \mu \mathrm{M}$ deoxynucleotide triphosphate, 10X PCR buffer of $p \mathrm{H}-8.3$ containing $15 \mathrm{mM} \mathrm{MgCl}_{2}$, and 5 units of Taq DNA polymerase (New England Biolabs, Beverly) [11]. DNA was initially denatured at $95^{\circ} \mathrm{C}$ for $4 \mathrm{~min}$ prior to amplification. A $250 \mathrm{bp}$ of catalase gene was amplified using the following conditions with 30 cycles consisting of $1 \mathrm{~min}$ denaturation at $94^{\circ} \mathrm{C}, 40 \mathrm{sec}$ annealing at $61^{\circ} \mathrm{C}$, and $1 \mathrm{~min}$ extension at $72^{\circ} \mathrm{C}$. The final extension included $5 \mathrm{mins}$ at $72^{\circ} \mathrm{C}$ and the PCR products were confirmed by ethidium bromide stained 1.2 percent agarose gel and viewed in the UVtransilluminator (Figure 1).

2.4. Restriction Enzyme Analysis. Restriction digestion was performed in a total volume of $10 \mu \mathrm{L}$ consisting of $5 \mu \mathrm{L}$ amplicon, $1 \mu \mathrm{L}$ NE buffer $(50 \mathrm{mM}$ potassium acetate, $20 \mathrm{mM}$ Tris-acetate, $10 \mathrm{mM}$ magnesium acetate, and $1 \mathrm{mM}$ dithiothreitol pH-7.9 at $25^{\circ} \mathrm{C}$ ), and $10 \mathrm{U}$ of Hinf 1 enzyme (Fermentas Life Sciences, Germany) [11]. Samples were incubated

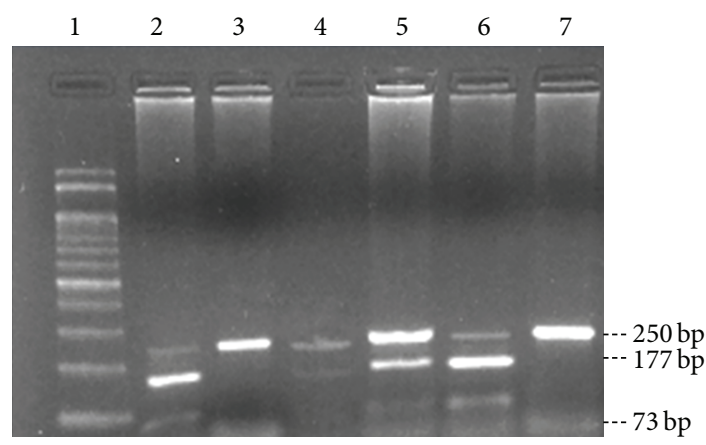

Lane 1: molecular weight marker (100 bp)

Lane 2 and 6: wild genotype (AA)-177bp and $73 \mathrm{bp}$.

Lane 3 and 7: variant genotype (TT)-250 bp

Lane 4 and 5: heterozygous genotype (AT)-250 bp, $177 \mathrm{bp}$, and $73 \mathrm{bp}$

FIGURE 2: Restriction band pattern of catalase $(-21 \mathrm{~A} / \mathrm{T})$ gene variant.

TABLE 1: Catalase gene -21 A/T polymorphism-genotype and allele frequency in healthy controls.

\begin{tabular}{lc}
\hline Genotype/Allele & Healthy controls $(n=100)$ \\
\hline Genotypes (-21 A/T) & 7 \\
AA & 23 \\
AT & 70 \\
TT & \\
Alleles & 0.18 \\
A & 0.82 \\
T & \\
\hline
\end{tabular}

for $6-7 \mathrm{hrs}$ at $37^{\circ} \mathrm{C}$ and the digested PCR products were resolved in 2 percent agarose gel electrophoresis stained with ethidium bromide and separated bands were observed using gel documentation system (Figure 2). The $\mathrm{A} \rightarrow \mathrm{T}$ mutation at nucleotide $250 \mathrm{bp}$ abolishes a Hinf 1 restriction site ( $T$ allele), which otherwise forms 177 and $73 \mathrm{bp}$ fragments (A allele) when treated with Hinfl. The catalase gene (-21) polymorphism abolishes a Hinf 1 site and so there will not be any cleavage of the PCR products $(250 \mathrm{bp}$ ) and if there is no mutation (normal genotype-AA), the band pattern in the gel will show the cleavage of the fragment into $177 \mathrm{bp}$ and $73 \mathrm{bp}$. In the case of heterozygous genotype (AT), all the three types of fragments ( $250 \mathrm{bp}, 177 \mathrm{bp}$, and $73 \mathrm{bp}$ ) will be observed in the gel.

2.5. Sequencing of the CAT Gene. The PCR product obtained was subjected to DNA sequencing which was carried out by Sanger's sequencing method (Synergy scientific services, Chennai) [12]. The DNA sequencing was done to check and confirm whether the amplified product was CAT gene sequence or not. The obtained sequence was then subjected to the BLAST N [13] analysis to study the homology sequence of the amplified product. 
TABLE 2: Prevalence of the catalase gene $-21 \mathrm{~A} / \mathrm{T}$ polymorphism in healthy controls.

\begin{tabular}{|c|c|c|c|c|c|c|}
\hline \multirow{2}{*}{ Country } & \multirow{2}{*}{ Ethnic population } & \multirow{2}{*}{ Number of subjects } & \multicolumn{3}{|c|}{ Genotype frequency } & \multirow{2}{*}{$\mathrm{T}$ allele frequency } \\
\hline & & & $\mathrm{A} / \mathrm{A}$ & $\mathrm{A} / \mathrm{T}$ & $\mathrm{T} / \mathrm{T}$ & \\
\hline India & $\begin{array}{l}\text { South Indian } \\
\text { (present study) }\end{array}$ & 100 & 7 & 23 & 70 & 0.82 \\
\hline Brazil [24] & Brazilian & 124 & 18.4 & 42.4 & 39.2 & 0.604 \\
\hline Finland [11] & Finnish & 245 & 18 & 48 & 34 & 0.58 \\
\hline Brazil [25] & Brazilian & 135 & 22 & 39 & 39 & 0.57 \\
\hline Czech Republic [15] & Czechs & 180 & 37 & 48 & 15 & 0.40 \\
\hline China $[5]$ & Chinese & 848 & 32 & 56 & 12 & 0.40 \\
\hline China [2] & Chinese & 386 & 54 & 38 & 8 & 0.272 \\
\hline New Zealand [16] & Europeans & 190 & 48 & 42 & 10 & 0.31 \\
\hline
\end{tabular}

\section{Results and Discussion}

The -21 A/T (rs7943316) polymorphism in CAT gene gains its importance mainly by its position being close to transcription start site, or at sites where the transcription factors bind [14]. In the present study, one hundred healthy volunteers were analysed for SNP in catalase $-21 \mathrm{~A} / \mathrm{T}$ gene polymorphism. It has been observed that only $7 \%$ of the individuals have AA genotype and $70 \%$ of individuals have TT genotype and the remaining $23 \%$ of individuals have AT heterozygous mutant genotype (Table 1). The highest TT genotype (70\%) of $21 \mathrm{~A} / \mathrm{T}$ catalase gene polymorphism was observed among south Indians and the lowest TT genotype (8\%) was observed among Chinese population [2].

When BLAST $\mathrm{N}$ analysis was performed with the DNA sequence of PCR product ( $250 \mathrm{bp}), 98$ percent homology was found between the CAT gene and the submitted DNA sequence. The " $\mathrm{T}$ " allele frequency observed in the present study was found to be very high $(0.82)$ when compared to that of Finnish population (0.58) [11], Czechs (0.4) [15], Europeans (0.31) [16], and Chinese $(0.4,0.2)[2,5]$ (Table 2). A study conducted among Indian population with diabetes mellitus has reported that $80 \%$ of the patients were of TT genotype and $20 \%$ were of AT genotype. AA genotype was not observed among patients and healthy individuals were not included in their study. The study also found lower activity of scavenger enzymes in patients with diabetes mellitus [9]. However, decreased catalase activity can be influenced by the disease itself and not by gene polymorphism.

Catalase is one of the major enzyme components of cell defense against oxidative stress and it has been hypothesized that the polymorphism of $-21 \mathrm{~A} / \mathrm{T}$ CAT reduces the antioxidant capacity and may serve as a risk factor for oxidative stress associated diseases. The association between SOD1$251 \mathrm{~A} / \mathrm{G}, \mathrm{CAT}-21 \mathrm{~A} / \mathrm{T}$, and GPX1-198C/T antioxidant gene polymorphisms in the risk of cataract was reported among Chinese population and was found to have no significant association in CAT-21 A/T and GPX1-198C/T polymorphisms between the controls and patients. However, SOD1-251 A/G polymorphism was found to be associated with an increased risk of cataract [2].

Experimental and clinical studies conducted among essential hypertension and cerebral stroke patients suggested that the polymorphism -21 A/T CAT was associated with increased risk and was found to play an important role in pathogenesis [17]. Similar study conducted among Russian population reported that there was an association between polymorphism -21 A/T of the catalase gene and bronchial asthma. The study also reported that cigarette smoking and fruits and vegetables intake have potentially inverse modifying influences on the risk of asthma [18]. In contrast few studies reported that the catalase gene polymorphism was not related to the risk of cardiovascular diseases among type 2 diabetes mellitus in Finnish population [11] and also among type 1 diabetes mellitus patients in Czech population [15].

Even though, catalase was not essential for some cell types under normal conditions, it was reported to play an important role in the adaptive response to oxidative stress $[19,20]$. Earlier studies reported that the catalase activity was found to be higher among cancer patients. However it has been reported that an adaptive increase of catalase activity may not be sufficient for inactivation of reactive oxygen species [21]. Decreased catalase gene expression due to the presence of mutant allele may further decrease the activity of catalase enzyme. The presence of insufficient antioxidant enzyme system may increase the susceptibility to oxidative stress-associated diseases among south Indian population.

Apart from -21 A/T polymorphism of the catalase gene, another polymorphism $(-262 \mathrm{C} / \mathrm{T})$ in the promoter region has been shown to influence transcription factor binding and correlates well with blood catalase levels [22]. There has been a well-established association between the type 1 diabetic neuropathy patients and the latter polymorphism in the Russian population [23].

In conclusion, the present study demonstrates that CAT $(-21 \mathrm{~A} / \mathrm{T}) \mathrm{SNP}$ is more prevalent among the south Indian population. Further study should be conducted to find out whether there is alteration in catalase activity in the individuals with mutant genotype for CAT $(-21 \mathrm{~A} / \mathrm{T})$ polymorphism among healthy individuals and also need to be correlated with any disease associated with oxidative stress such as cancer, diabetes, and coronary artery diseases. The other polymorphisms within the same gene should also be studied for better understanding of the role of catalase gene in the mediation of oxidative stress response. 


\section{Conflict of Interests}

The authors declare that there is no conflict of interests regarding the publication of this paper.

\section{Acknowledgment}

Financial assistance by Science and Engineering Research Board (SERB), New Delhi, in the form of Young Scientist Scheme (Fast Track) to Dr. T. Angeline is greatly acknowledged.

\section{References}

[1] J. E. Klaunig, L. M. Kamendulis, and B. A. Hocevar, "Oxidative stress and oxidative damage in carcinogenesis," Toxicologic Pathology, vol. 38, no. 1, pp. 96-109, 2010.

[2] Y. Zhang, L. Zhang, D. Sun, Z. Li, L. Wang, and P. Liu, "Genetic polymorphisms of superoxide dismutases, catalase, and glutathione peroxidase in age-related cataract," Molecular Vision, vol. 17, pp. 2325-2332, 2011.

[3] Y. Kono and I. Fridovich, "Superoxide radical inhibits catalase," The Journal of Biological Chemistry, vol. 257, no. 10, pp. 5751$5754,1982$.

[4] X. F. Zhou, J. Cui, A. L. Destefano et al., "Polymorphisms in the promoter region of catalase gene and essential hypertension," Disease Markers, vol. 21, no. 1, pp. 3-7, 2005.

[5] D. Chang, Z. L. Hu, L. Zhang et al., "Association of catalase genotype with oxidative stress in the predication of colorectal cancer: modification by epidemiological factors," Biomedical and Environmental Sciences, vol. 25, no. 2, pp. 156-162, 2012.

[6] A. Ceriello, A. Morocutti, F. Mercuri et al., "Defective intracellular antioxidant enzyme production in type 1 diabetic patients with nephropathy," Diabetes, vol. 49, no. 12, pp. 2170-2177, 2000.

[7] A. D. Hodgkinson, T. Bartlett, P. J. Oates, B. A. Millward, and A. G. Demaine, "The response of antioxidant genes to hyperglycemia is abnormal in patients with type 1 diabetes and diabetic nephropathy," Diabetes, vol. 52, no. 3, pp. 846-851, 2003.

[8] F. Quan, R. G. Korneluk, M. B. Tropak, and R. A. Gravel, "Isolation and characterization of the human catalase gene," Nucleic Acids Research, vol. 14, no. 13, pp. 5321-5335, 1986.

[9] K. Dhanapal, N. Selvan, and V. Dhananjeyan, "A study on catalase activity and its genetic polymorphism in diabetes mellitus patients," Journal of Biological Sciences, vol. 10, no. 7, pp. 653-657, 2010.

[10] V. M. Iranpur and A. K. Esmailizadeh, Rapid Extraction of High Quality DNA from Whole Blood Stored at $4^{\circ} \mathrm{C}$ for Long Period, Department of Animal Science, Faculty of Agriculture, Shahrekord University, Shahrekord, Iran, 2010.

[11] O. Ukkola, P. H. Erkkilä, M. J. Savolainen, and Y. A. Kesäniemi, "Lack of association between polymorphisms of catalase, copper-zinc superoxide dismutase (SOD), extracellular SOD and endothelial nitric oxide synthase genes and macroangiopathy in patients with type 2 diabetes mellitus," Journal of Internal Medicine, vol. 249, no. 5, pp. 451-459, 2001.

[12] F. Sanger and A. R. Coulson, "A rapid method for determining sequences in DNA by primed synthesis with DNA polymerase," Journal of Molecular Biology, vol. 94, no. 3, pp. 441-448, 1975.

[13] D. W. Mount, Sequence \& Genome Analysis, Cold Spring Harbor Laboratory Press, 2nd edition, 2004.
[14] N. M. Panduru, E. Moța, M. Moța, D. Cimponeriu, C. Serafinceanu, and D. M. Cheţa, "Polymorphism of catalase gene promoter in Romanian patients with diabetic kidney disease and type 1 diabetes," Romanian Journal of Internal Medicine, vol. 48, no. 1, pp. 81-88, 2010.

[15] M. Flekac, J. Skrha, J. Hilgertova, Z. Lacinova, and M. Jarolimkova, "Gene polymorphisms of superoxide dismutases and catalase in diabetes mellitus," BMC Medical Genetics, vol. 9, article 30, 2008.

[16] R. P. Young, R. Hopkins, P. N. Black et al., "Functional variants of antioxidant genes in smokers with COPD and in those with normal lung function," Thorax, vol. 61, no. 5, pp. 394-399, 2006.

[17] E. K. Vialykh, M. A. Solodilova, O. Y. Bushueva, I. V. Bulgakova, and A. V. Polonikov, "Catalase gene polymorphism is associated with increased risk of cerebral stroke in hypertensive patients," Zhurnal Nevrologii i Psihiatrii imeni S.S. Korsakova, vol. 112, no, 8, pp. 3-7, 2012.

[18] A. V. Polonikov, V. P. Ivanov, M. A. Solodilova, M. A. Kozhuhov, and V. I. Panfilov, "Tobacco smoking, fruit and vegetable intake modify association between $-21 \mathrm{~A}>\mathrm{T}$ polymorphism of catalase gene and risk of bronchial asthma," Journal of Asthma, vol. 46, no. 3, pp. 217-224, 2009.

[19] J. M. Mates, C. Perez-Gomez, and I. N. de Castro, "Antioxidant enzymes and human diseases," Clinical Biochemistry, vol. 32, no. 8, pp. 595-603, 1999.

[20] P. Venditti, P. Masullo, S. Di Meo, and C. Agnisola, "Protection against ischamia-reperfusion induced oxidative stress by vitamin E treatment," Archives of Physiology and Biochemistry, vol. 107, no. 1, pp. 27-34, 1999.

[21] D. Hristozov, V. Gadjeva, T. Vlaykova, and G. Dimitrov, "Evaluation of oxidative stress in patients with cancer," Archives of Physiology and Biochemistry, vol. 109, no. 4, pp. 331-336, 2001.

[22] L. Forsberg, L. Lyrenäs, U. de Faire, and R. Morgenstern, "A common functional C-T substitution polymorphism in the promoter region of the human catalase gene influences transcription factor binding, reporter gene transcription and is correlated to blood catalase levels," Free Radical Biology and Medicine, vol. 30, no. 5, pp. 500-505, 2001.

[23] D. A. Chistiakov, E. V. Zotova, K. V. Savost'anov et al., "The $262 \mathrm{~T}>\mathrm{C}$ promoter polymorphism of the catalase gene is associated with diabetic neuropathy in type 1 diabetic Russian patients," Diabetes and Metabolism, vol. 32, no. 1, pp. 63-68, 2006.

[24] A. L. Miranda-Vilela, A. K. Akimoto, P. C. Alves et al., "Dietary carotenoid-rich pequi oil reduces plasma lipid peroxidation and DNA damage in runners and evidence for an association with MnSOD genetic variant -Val9Ala," Genetics and Molecular Research, vol. 8, no. 4, pp. 1481-1495, 2009.

[25] A. L. Miranda-Vilela, P. C. Z. Alves, A. K. Akimoto et al., "Gene polymorphisms against DNA damage induced by hydrogen peroxide in leukocytes of healthy humans through comet assay: a quasi-experimental study," Environmental Health, vol. 9, article 21, 2010. 

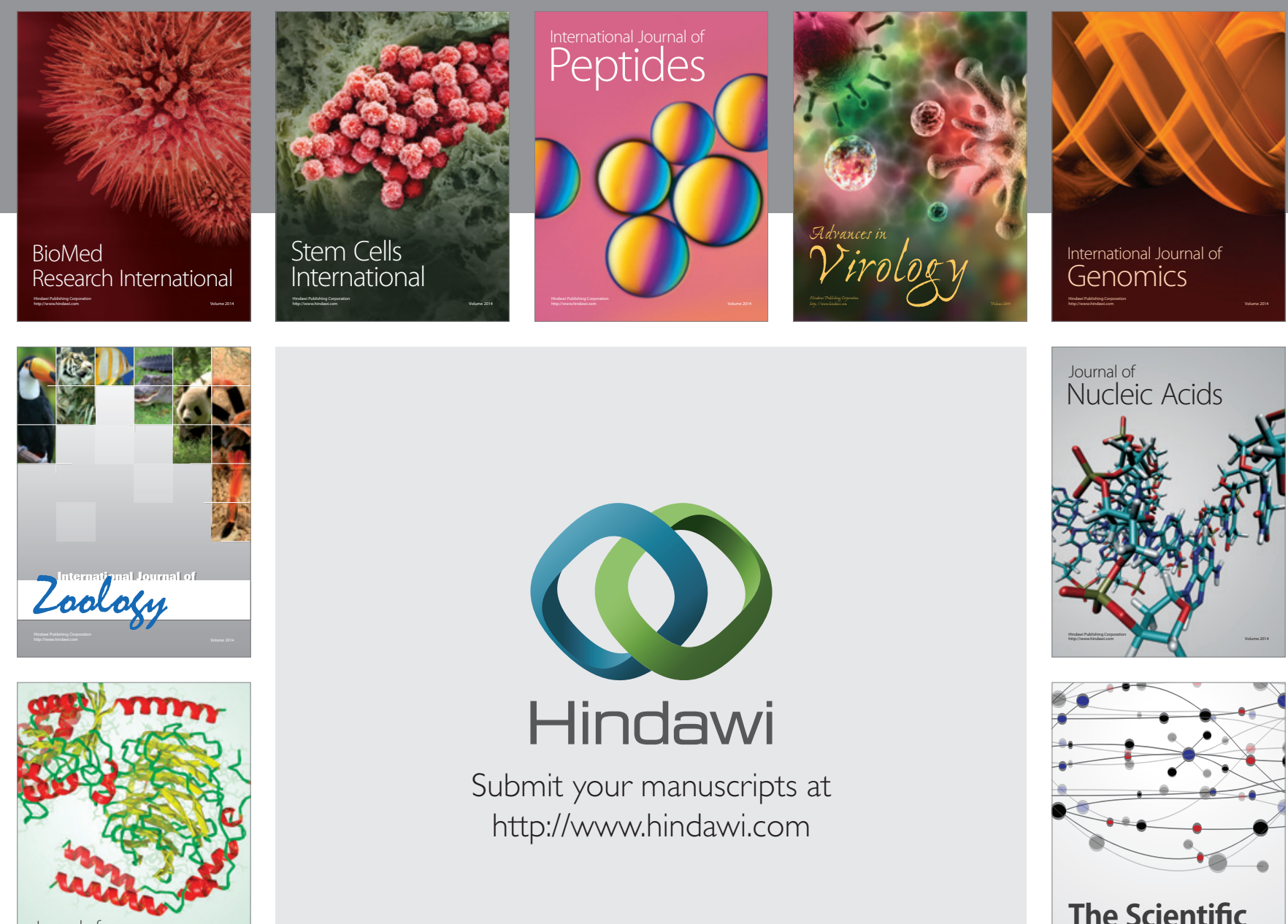

Submit your manuscripts at

http://www.hindawi.com

Journal of
Signal Transduction
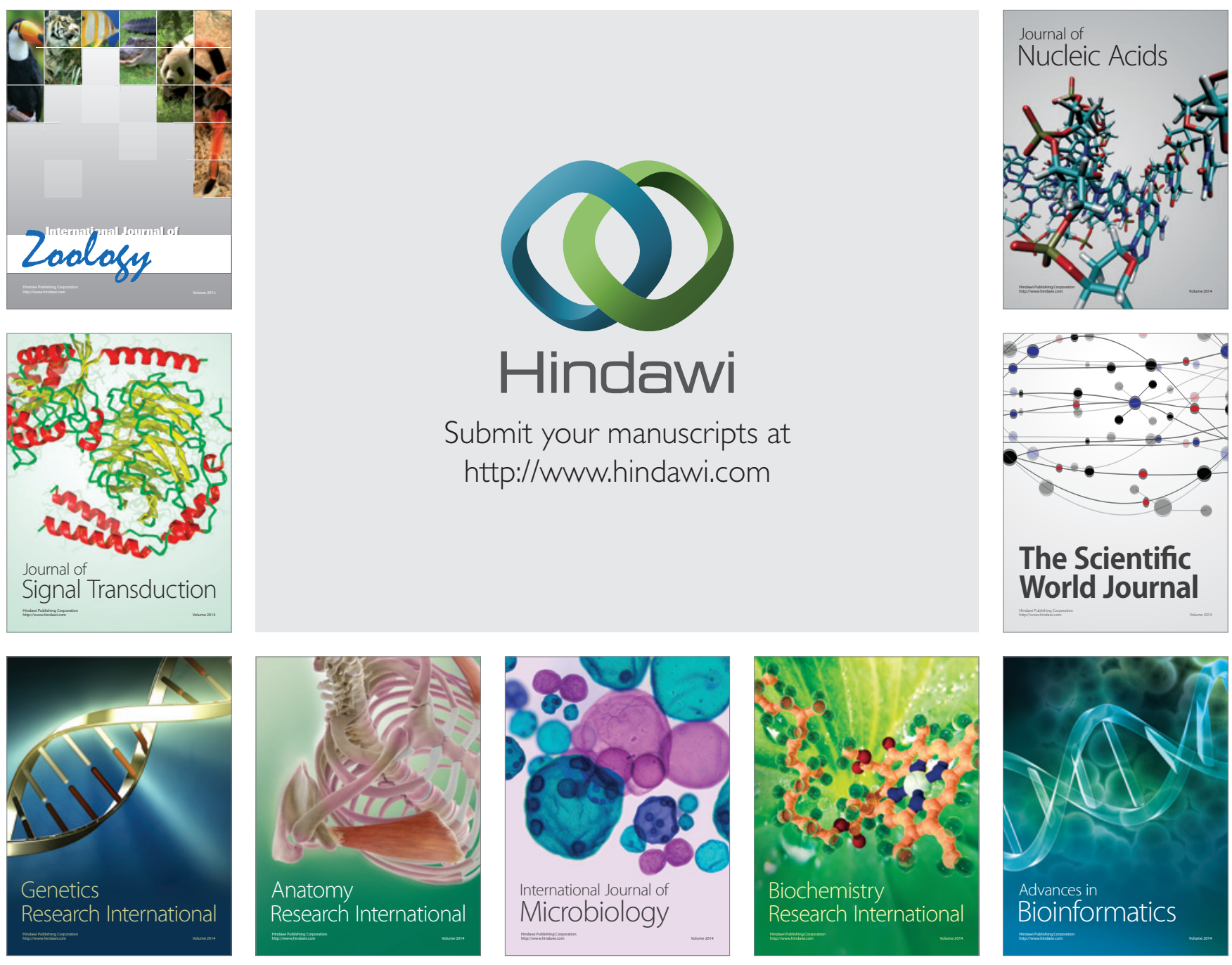

The Scientific World Journal
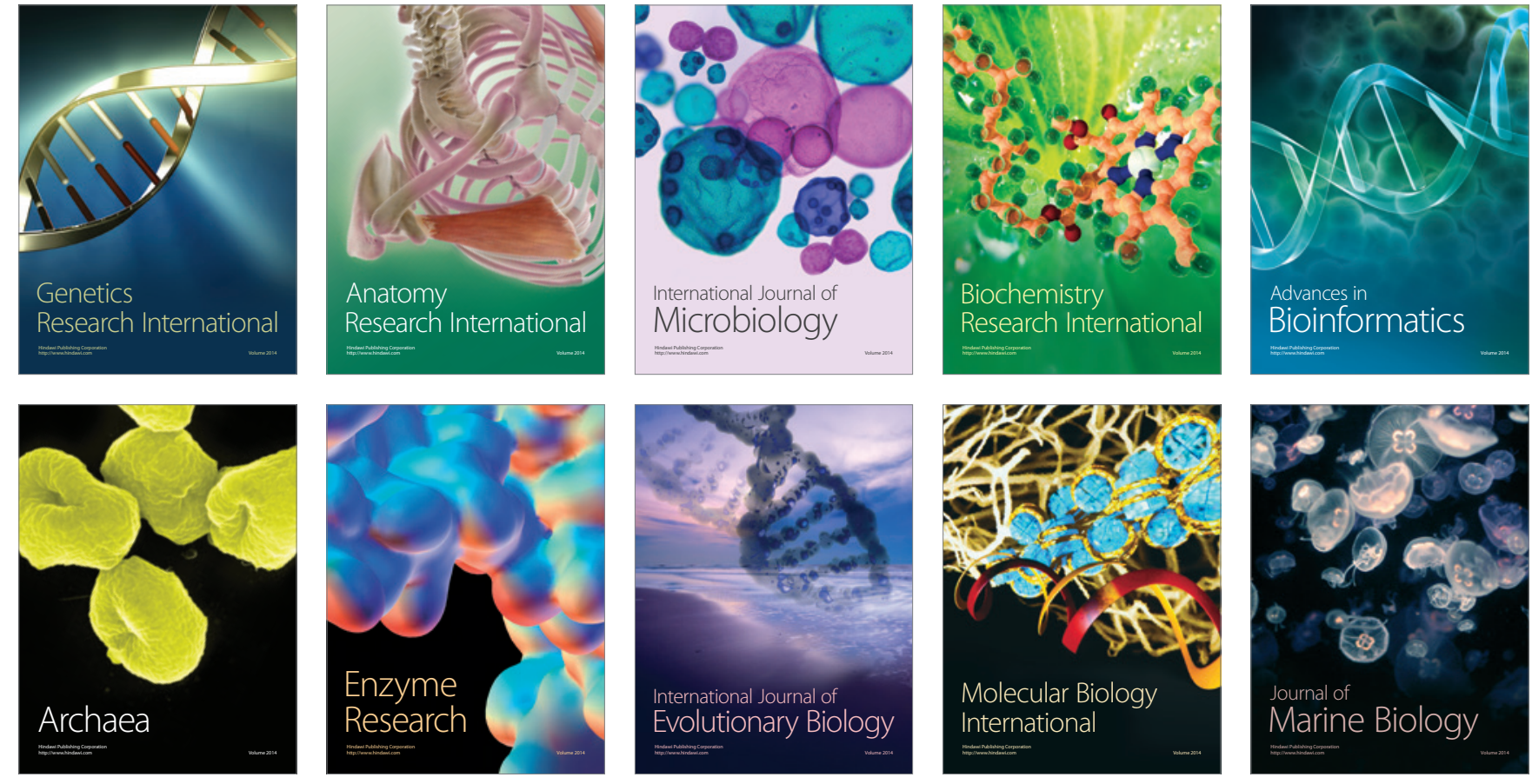